\title{
Effect of natural zeolite as substrate filler on the properties of NBR/ EPDM blend
}

\author{
Hesty Eka Mayasari ${ }^{1 *}$, Noor Maryam Setyadewi² \\ ${ }^{1}$ Center for Research and Standardization of Surabaya, Jl. Jagir Wonokromo No. 360, Surabaya 60244, Indonesia \\ ${ }^{2}$ Center for Leather, Rubber and Plastics, Jl. Sokonandi No. 9, Yogyakarta 55166, Indonesia \\ *Corresponding author. Tel.: +62 3199843670 , Fax: +62 318410480 \\ E-mail: hestyeka@kemenperin.go.id
}

Submitted: 8 February 2019

Revised: 21 May 2019

Accepted: 23 May 2019

\begin{abstract}
The NBR/EPDM blend has great ozone, oil, and heat resistance. Carbon black is the most common used filler material for rubber goods. But, it is less environmentally friendly and less healthy friendly. In this study, it would be studied the use of natural zeolite as a substitute for the filler. This blend was carried out by a two-roll mill and tested by rheometer and tensile strength tester. From the research that has been done, it was known that vulcanizate with carbon black was better than all of the vulcanizate using zeolite as filler substitute. Vulcanizate with CB provided the fastest curing time, the fastest reaction speed and also the best mechanical properties. Vulcanization with the $10 \mathrm{phr}$ zeolite gives the optimum curing time and the best mechanical properties compared to the substitution of other fillers. This shows that $10 \mathrm{phr}$ zeolite (16.7\%) can be a suitable filling material for NBR/ EPDM blend.
\end{abstract}

Keywords: NBR/EPDM, zeolite, filler, natural.

\section{INTRODUCTION}

Synthetic rubber is derived from petroleum. It is made to overcome the weaknesses of natural rubber. Nitrile butadiene rubber (NBR) has good solvent and oil resistance properties but has poor heat and ozone resistance. NBR is synthetic rubber containing acrylonitrile (ACN) and butadiene which determines its polarity and also the heat and oil resistance (Jovanović et al., 2009; Indrajati et al., 2012; Kantala et al., 2009; Jovanović et al., 2013). Ethylene diene monomer butadiene rubber (EPDM) is a nonpolar synthetic rubber that has ethylidine-2-norbornene (ENB) content. The higher the ENB content, the more sensitive EPDM to thermal oxidation, and the easier to degrade. EPDM has good ozone and heat resistance but is less resistant to nonpolar solvents (Jovanović et al., 2013; Ning et al., 2014; Mayasari \& Yuniari, 2016). Nowadays, researchers try to blend two or more rubber to get excellent rubber properties. The blend of rubber can improve the weakness of one rubber by the excellence of another rubber. The blend of NBR and EPDM can produce composites with better heat, oil, and ozone resistance than NBR or EPDM composites separately as previous research by Jovanović et al. (2013).

Carbon black (CB) is commonly used as filler in making rubber goods because it has good properties and cheap. CB can improve the mechanical properties of rubber goods (Jovanović et al., 2013). However, various types of pollution arise in the process of making $\mathrm{CB}$, which can be a problem for the environment. In addition, $\mathrm{CB}$ dust can cause serious health impact. Therefore, nowadays, many efforts are attempted to substitute CB such as activated carbon (Marlina et al., 2014), clay (De Sousa et al., 2011), silica (Ahmed et al., 2013), and zeolite (Pajarito et al., 2017).

Zeolite is an alumina-silicate-hydrate mineral that has a structure in three dimensions and contains alkaline-earth cation. It can be derived from natural and synthetic ingredients. Zeolites in nature are generally pure, easily available and inexpensive. It is widely used in the environmental, petroleum, chemical, and agricultural industries (Rianto et al., 2012; Wustoni et al., 2011; Fang et al., 2015). Nowadays, the zeolite is widely developed and investigated as a filler, such as for NR/NBR blend (Siriyong \& Keawwattana, 2012), NBR (Petrova et al., 2015), NR (Pajarito et al., 2017). Zeolite can be used directly or with activation, both physically (Wiyantoko et al., 2017) and chemically (Aidha, 2013; Utami, 2017). It has good thermal resistance, high surface area and has the ability to absorb polymers. Because zeolite is a kind of silica (inorganic silica), so it can be used as rubber filler (Fang et al., 2015). However, research on the NBR/ EPDM rubber blend with zeolite as fillers is still limited, especially using modified zeolite.

In this present study, zeolite was combined with $\mathrm{CB}$ as filler in the NBR/EPDM blends. The effect of zeolite substitution was studied in the terms of the cure characteristics and mechanical properties of the NBR/EPDM blend. These information are valuable in 
determining the suitable filler for NBR/EPDM blend.

\section{MATERIALS AND METHODS}

\section{Materials}

The materials used in this study were NBR (ACN 48.5\%, Krynac 4975 F), EPDM (ENB 8.7\%, Keltan 4551 A), carbon black N330 High Abrasion Furnace (HAF) (OCI, Korea), and natural zeolite from local market in Klaten, Indonesia as filler, paraffinic oil (Indrasari), paraffin wax (Antilux $654 \mathrm{~A}$ ) as antioxidant, stearic acid Aflux $42 \mathrm{M}$ (Rhein Chemie), and zinc oxide ( $\mathrm{ZnO}$, Indoxide) as activator, 6PPD (Starchem) as antiozonant, 2,2'dithiobis(benzothiazole) (MBTS) Kemai as accelerator, and sulfur (Miwon) as vulcanizing agent.

\section{Methods}

\section{Modification of zeolite}

Zeolite was modified by activated the natural zeolite physically by ground it in the mortar, then it was heated in an oven $100{ }^{\circ} \mathrm{C}$ for 6 hours.

\section{Rubber blends preparation}

NBR, EPDM, and additives were weighed according to the formulation in Table 1 and were blended using a tworoll mill. The NBR/EPDM compound were conditioned for 24 hours at room temperature. The compounds were then tested with a rheometer MDR Gotech 3000 A to determine the curing time of the compound and it was vulcanized by hydraulic press according to the time of the test results from the rheometer. The filler material was varied by $100 \%$ of $\mathrm{CB}, 91.2 \%$ of $\mathrm{CB}$ ( $5 \mathrm{phr}$ zeolite), and $83.3 \%$ of CB (10 phr zeolite) for both unmodified zeolite and modified zeolite.

\section{Curing characteristics}

The curing characteristics of NBR/EPDM blend can be studied from rheometer data. The compounds were tested by rheometer Gotech M-3000A in $160{ }^{\circ} \mathrm{C}$ within fixed angle and frequency of $3 \mathrm{deg}$. and $100 \mathrm{cps}$, respectively. The elastic torque (S'), viscous torque (S"), scorch time $\left(\mathrm{ts}_{2}\right)$, and optimum curing time $\left(\mathrm{tc}_{90}\right)$ were obtained. From these data, the cure rate index of compound can be studied. Cure rate index (CRI) can be calculated with equation (1).

$$
C R I=\frac{1}{\left(t c_{90}-t s_{2}\right)}
$$

The curing kinetics of NBR/EPDM compound also can be seen from the results of the rheometer test. The rate constant $(k)$ can be calculated by equation (2) as in the previous study (Yuniari et al., 2016)

$$
\ln \frac{\left(M_{H}-M_{L}\right)}{\left(M_{H}-M_{t}\right)}=k t
$$

The rate constant is obtained from the plot results from $\ln \left(M_{H}-M_{t}\right)$ results in a first order curing reaction which is indicated by a straight line.

\section{Mechanical properties}

The mechanical properties of the NBR/EPDM blend were studied using the tensile strength tester Kao Tieh to observe the tensile strength, elongation of the break, and tear strength.

\section{RESULTS AND DISCUSSION Curing Characteristics}

The curing process is an important stage that comes at the final stage in making rubber goods. At this stage, rubber compounds are heated within certain time, curing agents work onto the rubber molecular chains and crosslink one chain to another and form a network at the final. Heat is transferred through the surface into rubber material to become a strong elastic material (Jovanović et al., 2013).

The curing curve of the NBR/EPDM compound is shown in Figure 1. On this curve, it is already known that the curing process of the compound is divided into 3 stages, i.e. induction period, curing and overcure. Induction period is the initial stage, in which no vulcanization reaction takes place. Crosslinks are mainly formed from interaction between rubber and filler, or often called by physical crosslink. In this period, rubber compound should have better flow properties because it must fill the mold cavities within short time. Thus, the physical crosslink will play important role in compound flow characteristic. Higher physical crosslink hinders the compound to flow. The next phase is the curing phase in which vulcanization reaction takes place and crosslink increase rapidly. The rubber compound becomes harder and elastic. The last phase is overcure or the maturation phase of resulted crosslinks with prolong heating. Rubber compound responds differently with prolong heating after curing phase, namely reversion, equilibrium, and marching. These phenomena depends on the type of accelerator and sulphur ratio in the formulation. Reversion occurs when crosslinking decrease dramatically with the prolong heating after the curing phase. Equilibrium is indicated by the stable crosslink with prolong heating, and the marching is marked by increasing crosslinks over prolong heating (Leroy et al., 2013; Indrajati et al., 2014; Karaağaç et al., 2009). In the induction phase, addition of zeolite does not influence the graph. But in the curing phase, the higher addition of zeolite, the lower torque. The lower line from addition of $10 \mathrm{phr}$ zeolite shows the lower crosslink happened. In the overcure phase, the addition of zeolite does not affect the graph. All compounds show the marching phenomena.

Scorch time $\left(\mathrm{ts}_{2}\right)$ gives a sign for the end of the induction phase. It means that at $\mathrm{t}>\mathrm{ts}_{2}$, the vulcanization reaction takes place and crosslinks start to form. When compound reach scorch time, it will nearly stop to flow. Therefore, scorch time is often related to the scorch safety in which a safe time span for the compound before its molecules chain start to crosslink. The optimum curing time $\left(\mathrm{tc}_{90}\right)$ is the time needed to achieve the desired properties of final rubber goods. The optimum curing 
Table 1. Formulations of NBR/EPDM composites.

\begin{tabular}{lccccc}
\hline \multicolumn{1}{c}{ Materials } & NEZ0 & NEZ 5 & NEZ 5M & NEZ 10 & NEZ 10M \\
\hline NBR & 50 & 50 & 50 & 50 & 50 \\
EPDM & 50 & 50 & 50 & 50 & 50 \\
HAF CB N330 & 60 & 55 & 55 & 50 & 50 \\
Zeolite & 0 & 5 & 0 & 10 & 0 \\
Modified zeolite & 0 & 0 & 5 & 0 & 10 \\
Zinc Oxide & 5 & 5 & 5 & 5 & 5 \\
Stearic acid & 1 & 1 & 1 & 1 & 1 \\
Paraffinic oil & 2 & 2 & 2 & 2 & 2 \\
Paraffinic Wax & 0.5 & 0.5 & 0.5 & 0.5 & 0.5 \\
6 PPD Vulkanox & 5 & 5 & 5 & 5 & 5 \\
MBTS & 1.5 & 1.5 & 1.5 & 1.5 & 1.5 \\
Phenolic resin & 1 & 1 & 1 & 1 & 1 \\
Sulfur & 1.5 & 1.5 & 1.5 & 1.5 & 1.5 \\
\hline
\end{tabular}

time is taken when the compound is $90 \%$ mature. Because if we use $t_{c 100}$, we need extra energy thus higher cost. And, we give some time span to the rubber goods before they use (during storage they will mature slowly by the heat). So, when they are applied, they are in very good state. Figure 2 depicts the scorch and optimum curing time of the blends. It is clearly seen (Figure 2a) that 5 phr zeolite gives the longest scorch times either modified or unmodified. Further addition of zeolite $(10 \mathrm{phr})$ has markedly reduced scorch time for both types of zeolite. Generally, the addition of zeolite rises the optimum cure time $\left(\mathrm{tc}_{90}\right)$ and modification of zeolite does not affect it, as seen on Figure $2 \mathrm{~b}$. This probably deals with the nature of silica, the main substance presented on zeolite that tends to reduce the cure rate of rubber. Silica absorbs accelerators so that their amount are reduced and lowers the cure rate. While the curing time with $100 \%$ of CB gives the fastest time (326 seconds) compared to the compound with $\mathrm{CB}$ and zeolite fillers. The addition of $10 \mathrm{phr}$ zeolite without modification gives the lowest optimum curing time (341 seconds) compared to the substitution of other fillers. This can be affected by material compatibility. Modification of zeolite does not show an effect on the scorch time and optimum curing time. The addition of $5 \mathrm{phr}$ zeolite increases the scorch time but $10 \mathrm{phr}$ zeolite does not affect the scorch time. The addition of $5 \mathrm{phr}$ zeolite is more suitable than 10 phr zeolite.

Crosslinking in rubber can be monitored through

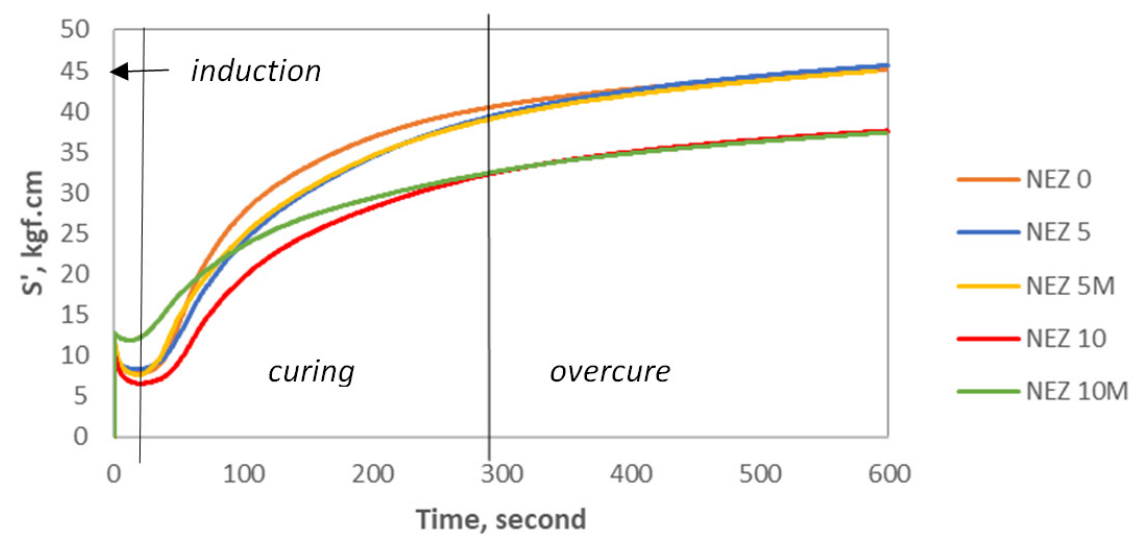

Figure 1. Curing curve of NBR/EPDM compound.

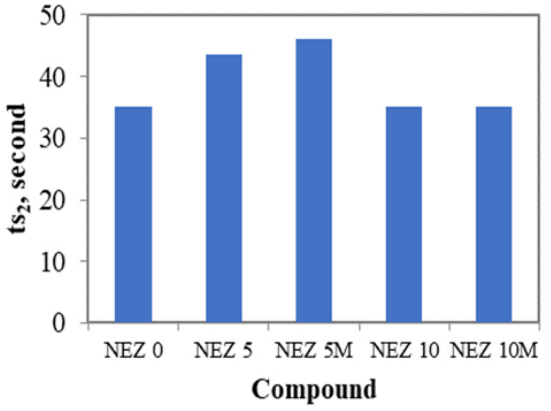

(a)

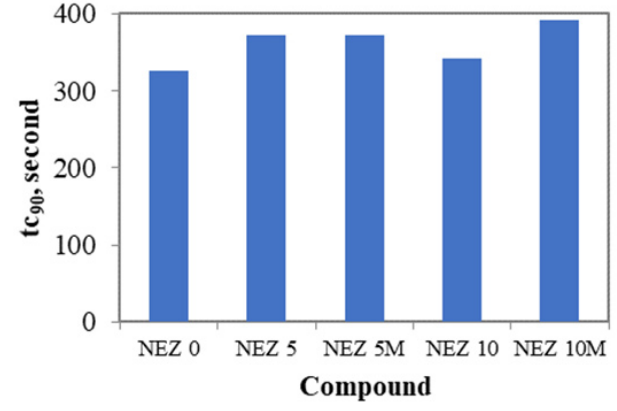

(b)

Figure 2. Scorch time (a) and optimum curing time (b) of NBR/EPDM compound. 
the rheometer torques changes. Crosslink formation stiffen the compound, then increase the torque. Minimum torque (ML) is a rough description of compound viscosity and related to the physical crosslinking. High ML will give negative impact to the compound during processing since it has high viscosity that leads to a slow flow (Indrajati et al., 2014). ML of the blends is comparable, thus it can be concluded that incorporation of zeolite does not change compound viscosity. The highest crosslink numbers formed during curing phase is monitored through the maximum elastic torque (MH). The addition of $5 \mathrm{phr}$ zeolite, both modified and unmodified, results in comparable crosslink numbers, but further addition of zeolite (10 phr) tends to reduce it. Modification of zeolite does not give significant effect to the crosslink. Crosslink density of rubber is often measured from the torque delta (MH-ML). The higher the delta MH and ML, the more crosslinking is formed (Nabil et al., 2013). It is clearly seen on Table 2 that incorporation of zeolite in the formulation does not result in an increase of crosslink density. Moreover, $10 \mathrm{phr}$ zeolite tends to decrease the crosslink density to certain level. This is probably related to the nature of silica that presents in higher amount in zeolite. Silica is known to retard the cure by absorbing the accelerator. Thus, it reduces the amount of accelerator involved in the curing phase and leads to a low crosslink density formation.

From the rheometer data, the minimum torque value (ML) and maximum torque value $(\mathrm{MH})$ of the viscous element (S") and an elastic element (S') of the rubber material are known. Rubber has viscoelastic properties whose ratio is represented by $\tan \delta$ (damping factor). Table 2 shows that $\tan \delta \mathrm{MH}$ is inversely proportional to delta torque. The higher the $\tan \delta \mathrm{MH}$, the less crosslinking is formed (Nabil et al., 2013). The viscoelastic curve of the NBR/EPDM compound is shown in Figure 3. Figure 3 shows that all compounds have an elastic area (S') larger than the viscous (S") region, this illustrates that the compound has high viscosity.

The cure rate index and the rate constant of curing can be seen from the rheometer test results. The curing rate index (CRI) shows the speed of the cure of compound which can be calculated from equation (1). While the reaction kinetics can be illustrated by the constant rate calculated from equation (2). From equations (1) and (2), the CRI values and constants rate are shown in Table 3.

From Table 3, it is known that CRI is directly proportional to the constant rate. The higher CRI, the faster vulcanization speed, so the time needed for curing is low. High constant rate indicates that the rubber matrix and filler material are easier to react. In Table 3 , it is known that NEZ 0 (60 phr CB), composite with all of the carbon black as filler, gives the highest constant rate compared to compounds with zeolite as substitute filler. The compound with $5 \mathrm{phr}$ modified zeolite gives higher reaction speed than 5 phr unmodified zeolite, while the compound with $10 \mathrm{phr}$ unmodified zeolite gives a slightly higher constant rate than modified zeolite. It may happen because the physical treatment given to zeolite does not affect the bond between zeolite and the rubber matrix.

\section{Mechanical Properties}

The rubber compounds with formulation given in Table 1 are then vulcanized to produce NBR/EPDM composites. The composites are then tested to determine their mechanical properties, including tensile strength, elongation, and tear strength. The mechanical properties of NBR/EPDM composites are shown in Figure 4.

From Figure 4, it is known that $\mathrm{CB}$, as filler, provides the best mechanical properties, both from tensile strength, elongation, and tear strength. Carbon black can be easily dispersed into the rubber matrix so that composite has high mechanical property (Jovanović et al., 2013). The high physical properties of the composite with $100 \%$ of $\mathrm{CB}$ filler is in accordance with the rheometer results which indicate that $100 \%$ of $\mathrm{CB}$ provides the highest delta torque that correlates with its mechanical properties (Alam et al., 2014). Zeolite as a substitute for filler does not provide significantly different results between $5 \mathrm{phr}$ and $10 \mathrm{phr}$ zeolite for tensile strength. Whereas, $10 \mathrm{phr}$ unmodified zeolite gives the highest elongation and tear strength. This

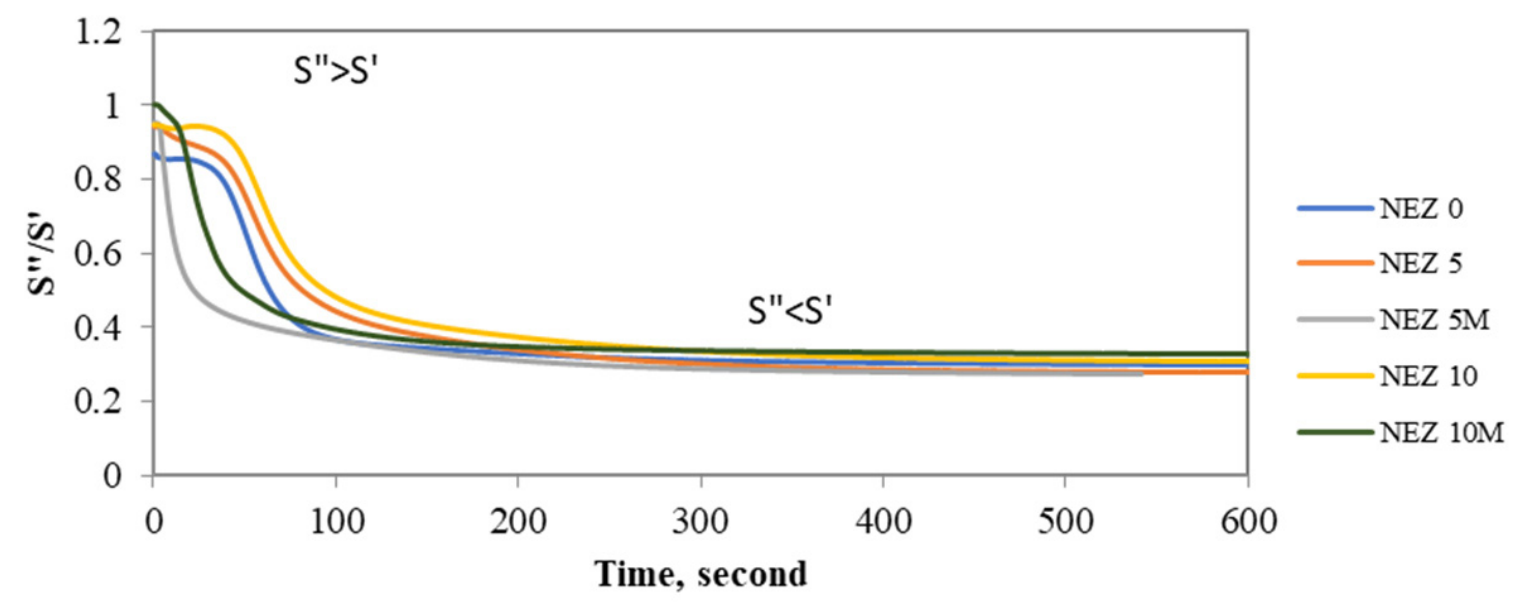

Figure 3. Tan $\delta$ curve of NBR/EPDM compound. 
Table 2. Rheometer torques and tan delta of NBR/EPDM blends.

\begin{tabular}{|c|c|c|c|c|c|c|c|}
\hline \multirow{2}{*}{ Compound ID } & S'MH & S'ML & S'MH & S'ML & \multirow{2}{*}{$\tan \delta(\mathrm{MH})$} & \multirow{2}{*}{$\tan \delta(\mathrm{ML})$} & $\mathrm{S}^{\prime}(\mathrm{MH}-\mathrm{ML})$ \\
\hline & kgf.cm & kgf.cm & kgf.cm & kgf.cm & & & kgf.cm \\
\hline NEZ 0 & 45.09 & 7.74 & 13.40 & 6.62 & 0.29 & 0.86 & 37.35 \\
\hline NEZ 5 & 45.10 & 8.08 & 12.33 & 6.97 & 0.27 & 0.86 & 37.02 \\
\hline NEZ 5M & 44.85 & 7.66 & 12.63 & 7.12 & 0.28 & 0.93 & 37.20 \\
\hline NEZ 10 & 37.20 & 6.50 & 11.53 & 6.18 & 0.31 & 0.95 & 30.70 \\
\hline NEZ 10M & 36.93 & 7.44 & 11.95 & 6.75 & 0.32 & 0.91 & 29.49 \\
\hline
\end{tabular}

Table 3. Results of the maturation velocity index calculation and reaction speed constants.

\begin{tabular}{lcc}
\hline \multicolumn{1}{c}{ Composite } & CRI & Constant rate, $k\left(\mathrm{~s}^{-1}\right)$ \\
\hline NEZ 0 & 0.35 & 0.0118 \\
NEZ 5 & 0.30 & 0.0079 \\
NEZ 5M & 0.31 & 0.0080 \\
NEZ 10 & 0.33 & 0.0084 \\
NEZ 10M & 0.28 & 0.0073 \\
\hline
\end{tabular}

is in accordance with previous studies which found that CB substitution with 8 phr zeolite produced the best tensile strength (Fang et al., 2015). The modification of zeolite which does not show an enhancement of the mechanical properties is possible because physical modification just minimizes the size but does not makes a better bond between zeolite and the rubber matrix. Modifications to zeolite are expected not only to enlarge the area but also to increase the interaction between zeolite and rubber. So that chemical modification is needed to improve zeolite as filler.

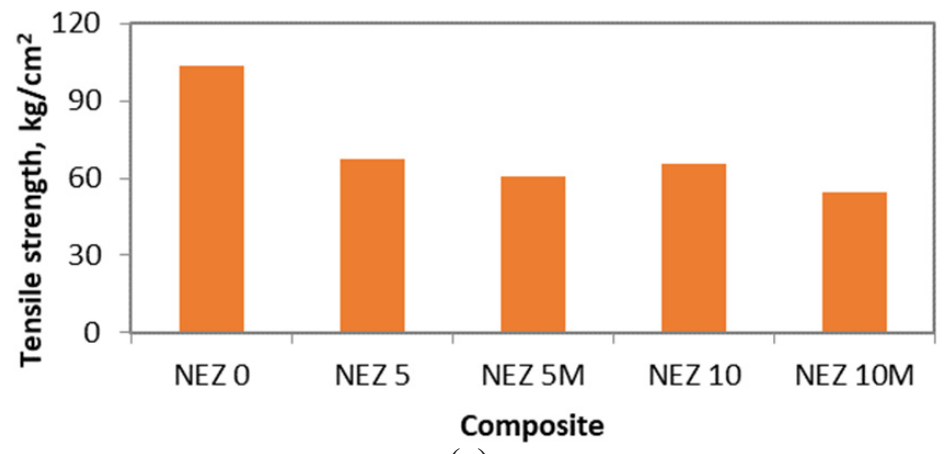

(a)

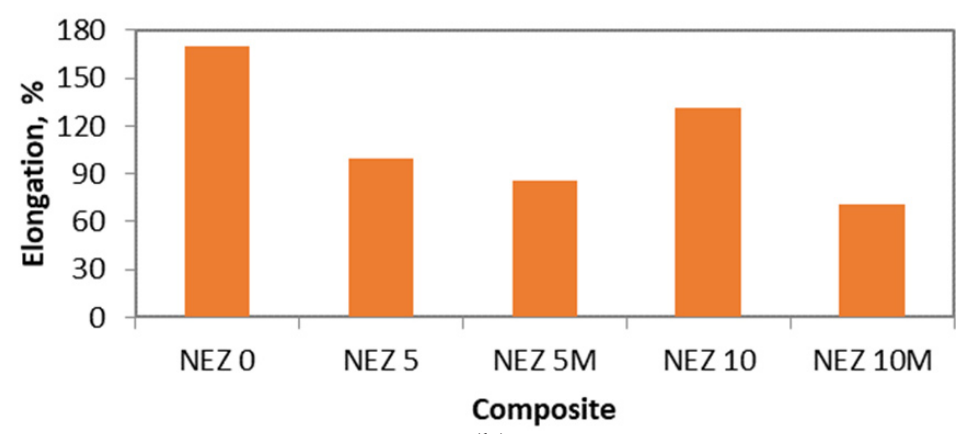

(b)

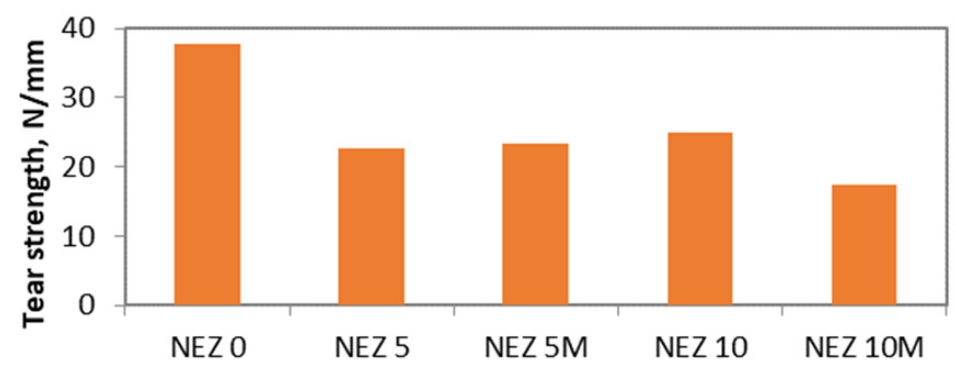

(c)

Figure 4. Mechanical properties of NBR/EPDM composite (a) tensile strength, (b) elongation at break, (c) tear strength. 


\section{CONCLUSIONS}

From the research that has been done, it is known that carbon black as filler gives better properties than carbon black substitute by zeolite. Compound with $100 \%$ of $\mathrm{CB}$ provides the fastest curing time (326 seconds), the highest curing rate index $(0.35)$, the highest constant rate $\left(0.0118 \mathrm{~s}^{-1}\right)$, and also the best mechanical properties (tensile strength $103.3 \mathrm{~kg} / \mathrm{cm}^{2}$, elongation $170 \%$, and tear strength $37.9 \mathrm{~kg} / \mathrm{cm}$ ). Compound with substitute $10 \mathrm{phr}$ zeolite $(16.7 \%)$ gives the higher optimum curing time (342 seconds), the higher cure rate index (0.33), the higher constant rate $\left(0.0084 \mathrm{~s}^{-1}\right)$, and also higher mechanical properties (tensile strength $65.5 \mathrm{~kg} / \mathrm{cm}^{2}$, elongation $131 \%$, and tear strength $25 \mathrm{~kg} / \mathrm{cm}$ ) than other substitution fillers. Physical modification of zeolite does not give a significant effect on rheology and mechanical properties of NBR/ EPDM compound. The substitution of $10 \mathrm{phr}$ zeolite (13.4\%) can be a suitable filler for NBR/EPDM blend. However, research on modification of zeolite as a filler material needs to be continued to obtain filler properties that are closer to carbon black.

\section{ACKNOWLEDGEMENTS}

The author would like to thank the Center for Leather, Rubber and Plastics for the funding of this research.

\section{REFERENCES}

Ahmed, K., Nizami, S. S., Raza, N. Z., \& Habib, F. (2013). The effect of silica on the properties of marble sludge filled hybrid natural rubber composites. Journal of King Saud University - Science, 25(4), 331-339. https://doi.org/10.1016/j.jksus.2013.02.004

Aidha, N. N. (2013). Aktivasi zeolit secara fisika dan kimia untuk menurunkan kadar kesadahan ( $\mathrm{Ca}$ dan $\mathrm{Mg}$ ) dalam air tanah. Jurnal Kimia Kemasan, 35(1), 58-64. https://doi.org/10.24817/jkk.v35i1.1874

Alam, M. N., Mandal, S. K., Roy, K., \& Debnath, S. C. (2014). Synergism of novel thiuram disulfide and dibenzothiazyl disulfide in the vulcanization of natural rubber: Curing, mechanical and aging resistance properties. International Journal of Industrial Chemistry, 5(1), 1-11. https://doi.org/10.1007/s40090-014-0008-6

De Sousa, F. D. B., Mantovani, G. L., \& Scuracchio, C. H. (2011). Mechanical properties and morphology of NBR with different clays. Polymer Testing, 30(8), 819-825. https://doi.org/10.1016/j.polymertesting.2011.07.005

Fang, Q., Liu, X., Wang, N., Ma, C., \& Yang, F. (2015). The effect of zeolite particle modified by PEG on rubber composite properties. Science and Engineering of Composite Materials, 22(6), 607-612. https://doi.org/10.1515/secm-2013-0316

Indrajati, I. N., Dewi, I. R., \& Irwanto, D. (2012). Pengaruh variasi rasio $\mathrm{HAF} / \mathrm{SRF}$ terhadap sifat vulkanisat NBR. Majalah Kulit, Karet, dan Plastik, 28(2), 59-68. https://doi.org/10.20543/mkkp.v28i2.106

Indrajati, I. N., \& Sholeh, M. (2014). Pengaruh Rasio MBTS/ ZDEC pada campuran karet alam dan etilen propilen diena yang dibuat dengan teknik kontrol migrasi curatives. Majalah Kulit, Karet, dan Plastik, 30(1), 4352. https://doi.org/10.20543/mkkp.v30i1.124
Jovanović, V., Budinski-Simendić, J., Samardžija-Jovanović, S., Marković, G., \& Marinović-Cincović, M. (2009). The influence of carbon black on curing kinetics and thermal aging of acrylonitrile-butadiene rubber. Chemical Industry and Chemical Engineering Quarterly, 15(4), 283-289. https://doi.org/10.2298/CICEQ0904283J

Jovanović, V., Samaržija-Jovanović, S., BudinskiSimendić, J., Marković, G., \& MarinovićCincović, M. (2013). Composites based on carbon black reinforced NBR/EPDM rubber blends. Composites Part B: Engineering, 45(1), 333-340. https://doi.org/10.1016/j.compositesb.2012.05.020

Kantala, C., Wimolmala, E., Sirisinha, C., \& Sombatsompop, N. (2009). Reinforcement of compatibilized NR/NBR blends by fly ash particles and precipitated silica. Polymers for Advanced Technologies, 20(5), 448-458. https://doi.org/10.1002/pat.1293

Karaağaç, B., İnal, M., \& Deniz, V. (2009). Artificial neural network approach for predicting optimum cure time of rubber compounds. Materials \& Design, 30(5), 16851690. https://doi.org/10.1016/j.matdes.2008.07.010

Leroy, E., Souid, A., \& Deterre, R. (2013). A continuous kinetic model of rubber vulcanization predicting induction and reversion. Polymer Testing, 32(3), 575-582. https://doi.org/10.1016/j.polymertesting.2013.01.003

Marlina, P., Pratama, F., Hamzah, B., \& Pambayun, R. (2014). Karakteristik kompon karet dengan bahan pengisi arang aktif tempurung kelapa dan nano silika sekam padi. Jurnal Teknologi Industri Pertanian, 25(1), 85-93.

Mayasari, H. E., \& Yuniari, A. (2016). Karakteristik termogravimetri dan kinetika dekomposisi EPDM dengan bahan pengisi carbon black. Majalah Kulit, Karet, dan Plastik, 32(2), 125-134. https://doi.org/10.20543/mkkp.v32i2.1591

Nabil, H., Ismail, H., \& Azura, A. R. (2013). Compounding, mechanical and morphological properties of carbon-black-filled natural rubber/recycled ethylene-propylene-diene-monomer $\quad(\mathrm{NR} / \mathrm{R}$ EPDM) blends. Polymer Testing, 32(2), 385-393. https://doi.org/10.1016/j.polymertesting.2012.11.003

Ning, N., Ma, Q., Zhang, Y., Zhang, L., Wu, H., \& Tian, M. (2014). Enhanced thermo-oxidative aging resistance of EPDM at high temperature by using synergistic antioxidants. Polymer Degradation and Stability, 102(1), 1-8. https://doi.org/10.1016/j.polymdegradstab.2014.01.037

Pajarito, B. B., Gines, K. A., Baluyut, A. S., de Leon, J. A. A., \& Villa, R. P. (2017). Effect of replacing carbon black with organo-modified bentonite and acid-activated zeolite on vulcanization characteristics of natural rubber tire tread. Materials Science Forum, 890, 59-63. https://doi.org/10.4028/www.scientific.net/MSF.890.59

Petrova, N. N., Lee, J., Portnyagina, V. V., Jeong, D. Y., \& Cho, J. H. (2015). Antiswelling and frost-resistant properties of a zeolite-modified rubber mechanical seal at low temperature. Bulletin of the Korean Chemical Society, 36(2), 464-467.

Rianto, L. B., Amalia, S., \& Khalaifah, S. N. (2012). Pengaruh impregnasi logam titanium pada zeolit alam malang terhadap luas permukaan zeolit. Alchemy, 2(1), 58-67.

Siriyong, T., \& Keawwattana, W. (2012). Utilization of different curing systems and natural zeolite as filler and absorbent for natural rubber/nitrile rubber blend. Kasetsart Journal - Natural Science, 46(6), 918-930.

Utami, I. (2017). Aktivasi zeolit sebagai adsorben gas $\mathrm{CO}_{2}$. 
Jurnal Teknik Kimia, 11(2), 51-55.

Wiyantoko, B., Andri, P. N., \& Anggarini, D. (2017). Pengaruh aktivasi fisika pada zeolit alam dan lempung alam terhadap daya adsorpsinya. In Prosiding Seminar Nasional Kimia dan Pembelajarannya (pp. 120-128).

Wustoni, S., Mukti, R., Wahyudi, A., \& Ismunandar. (2011). Sintesis zeolit mordenit dengan bantuan benih mineral alam indonesia sintesis zeolit mordenit dengan bantuan benih mineral alam indonesia. Jurnal Matematika \& Sains, 16(3), 158-160.

Yuniari, A., Setyorini, I., \& Mayasari, H. E. (2016). Kinetika vulkanisasi dan sifat mekanis komposit acrylonitrile butadiene rubber (NBR). Majalah Kulit, Karet, dan Plastik, 32(2), 117-124. https://doi.org/10.20543/mkkp.v32i2.1594 
